\title{
ANALISIS RASIO UNTUK MENGUKUR KINERJA PADA PT BANK MANDIRI PERSERO TBK (2015-2018)
}

\author{
Ressa Sasongko, Burhanudin, Rochmi Widayanti \\ Fakultas Ekonomi Jurusan Manajemen Universitas Islam Batik Surakarta \\ Email : sasongkoressa@gmail.com
}

\begin{abstract}
Financia lperformance can demonstrate bank quality by going through the calculation of financial ratios. The financial ratios of a bank can be done by analyzing the financial statements published periodically. To assess a financial performance in a banking need to be aware of the analysis and cumulative financial impact. The purpose of this research is to determine the performance of Bank Mandiri listed at IDX using liquidity ratio, solvency and profitability in the years 2015-2018. The research methods in this study use descriptive research types. Inthis study the data used is secondary data, with data collection Techniques that are documentation and library studies. From Bank Mandiri liquidity calculation, it shows good ratio or liquid. It can be seen from the current ratio, quick ratio, and cash ratio on Bank Mandiri's ability to meet the short term obligations have been made with good asset management, capital, and cash. The solvency of Bank Mandiri shows the ratio of good and solvable. It can be seen from the DAR and DER ratios that show a declining year-to-year ratio. The profitability of Bank Mandiri shows a fairly good ratio of figures despite the decline in 2016.
\end{abstract}

Keywords: financial performance, financial ratios, analysis of financial statements

\section{PENDAHULUAN}

\section{Latar Belakang}

Perkembangan perbankan sekarang telah sangat pesat dana disamping itu terdapat tingkat.kompleksitas yang. begitu tinggi, hal. ini dapat. berpengaruh terhadap. performa.dari suatu bank. Tingginya suatu resiko. dalam. suatu. bank dapat memicu.suatu kompleks usaha perbankan. (Ottay. dan .Alexander, 2015)

Kinerja bank secara umum mencakup pencapaian prestasi suatu abank. Dalam operasionalnya dan kondisi keuangan pada periode tertentu. Kinerja. keuangan menunjukkan kualitas maupun kesehatan bank melalui penghitungan rasio. Dengan menganalisis laporan keuangana yang dipublikasikan berkala. Dapat diperoleh rasio keuangan pada suatu bank. (Kusumo, .2008)

Laporan keuangan merupakan hasil dari banyak keputusan-keputusan suatu.perusahaan.dan dibuat secara rutin oleh.pihak manajemen. Menilai.suatu kinerja keuangan.dalam .suatu .perbankan perlu di ketahui adanya .analisa-analisa serta dampak.keuangan kumulatif (Manitik, 2103).

Kusumo (2008) menyatakan untuk menganalisis dan mengukur suatu laporan keuangan dapat menggunakan alat ukur rasio. Dengan rasio dapat menunjukkan hubungan pertimbangan antara jumlah keuangan tertentu dengan jumlah keuangan lainnya. Menurut Maith (2013), Analisis rasio diklarifikasikan dalam berbagai jenis, antara lain rasio likuiditas, rasio solvabilitas, dan rasio profitabilitas. Dengan mengetahui tingkat rasio suatu perusahaan, dapat diketahui keadaan/kesehatan perusahaan yang sesungguhnya sehingga tingkat kinerja keuangan pada perusahaan dapat diukur. 


\section{Tujuan Penelitian}

Untuk mengetahui atau menganalisis kinerja keuangan pada PT Bank Mandiri berdasarkan analisis rasioa likuiditas, solvabilitas, dana profitabilitas.

\section{KAJIAN PUSTAKA}

\section{Kinerja Keuangan}

Kinerja perusahan diartikan sebagai hasil yang telah dicapai oleh suatu perusahaan dengan mengolah sumber yang ada dalam perusahaan seefektif dan seefisien mungkin guna mencapai tujuan yang telah ditetapkan manajemen (Ottay dan Alexander, 2015). Pengertian kinerja keuangan perusahaan merupakan suatu kondisi tentang keuangan perusahaan yang telah dianalisis dengan alat-alat analisis keuangan, dengan tujuan mengetahui sehat atau tidaknya keadaan keuangan suatu perusahaan sehingga dapat memberikan petuntuk mengenai prestasi kerja dalam periode-periode yang telah ditentukan". (Wati, 2012)

Pongoh (2013) menyatakan kinerja keuangan merupakan proses analisis data yang dilakukan untuk mengetahui sejauh mana tingkat kesehatan atau pencapaian suatu bank dengan menggunakan standar aturan-aturan pelaksanaan keuangan yang baik. Dengan persyaratan laporan keuangan tersebut apakah sudah memenuhi standar dan ketentuan dalam SAK (Standar Akuntansi Keuangan) atau GAAP (General Aceptep Accounting Priciple), dan lainnya.

\section{Laporan Keuangan}

Menurut Meliangan, Tommy, dan Mekel (2014), Laporan keuangan adalah hasil perhitungan akuntansi yang digunakan sebagai alat ukur berkomunikasi antara data ke uangan atau aktivitas keuangan suatu perusahan.

Menurut Munawir (2012: 5) Laporan keuangan terdiri atas laporan laba rugi, neraca, dan perubahaan modal. Dari prinsip-prinsip Akutansi Indonesia dikatakan bahwa laporan keuangan adalah suatu perhitungan laba rugi serta neraca dan seluruh keterangan-keterangan yang telah ditulis/dihitung sebagai lampiran/buku antara lain penggunaan modal-modal dan sumber laporan dalam setiap perusahaan".

\section{Analisis Laporan Keuangan}

Maith (2013) berpendapat, analisis adalah perinciansuatu persoalan atau permasalahan serta menjelaskan hubungan antara bagian-bagian yang terdapat di dalamnya. Sedangkan laporan keuangan adalah suatu penyajian dari posisi

keuangan dan kinerja keuangan suatu entitas. Menurut Nuruwael dan Sitohang (2013), Rasio yang dapat digunakan untuk mengukur kinerja bank adalah sebagai berikut:

a. Rasio likuiditas

Likuiditas ratio adalah rasio yang menunjukkan kemampuan perusahaan dalam memenuhi kewajibannya dalam waktu jangka pendek. Rasio likuiditas terdiri dari Rasio lancar (current ratio), rasio cepat (quick ratio), dan rasio kas (cash ratio).

b. Rasio solvabilitas

Rasio solvabilitas adalah rasio yang menggambarkan kemampuan perusahaan memenuhi semua kewajiban-kewajibannya pada periode tertentu, baik jangka pendek maupun jangka panjang. 
c. Rasio Profitabilitas

Rasio profitabilitas adalah rasio yang menunjukkan kemampuan perusahaan untuk menghasilkan keuntungan dengan menggunakan modal.

\section{METODE PENELITIAN}

Jenis penelitian yang digunakan dalam penelitian ini adalah deskriptif. Menurut Narbuko dan Achmadi (2017 : 44) penelitian deskriptif yaitu mengklarifikasi, menganalisis, mengumpulkan data-data yang diperoleh suatu bank. Dalam hal ini penulis hanya memberikan gambaran yang sebenarnya atas masalah yang sedang dianalisis.

Menurut Timotius (2017 : 70) jenis data dalam penelitian ini dalah data kuantitatif. Data kuantitatif adalah data yang dikumpulkan dalam bentuk angka. Angka yang berhubungan dengan rasio keuangan meliputi rasio likuiditas, solvabilitas, dan profitabilitas pada PT. Mandiri persero. Yaitu laporan keuangan pada tahun 2015-2018.

Sumber data dalam penelitian ini yaitu data sekunder. Peneliti mengumpulkan datadata berupa laporan keuangan PT Mandiri persero dari sumber yang telah ada.

Teknik analisis data yang digunakan dalam penelitian ini menggunakan rasio keuangan. Rumus yang digunakan adalah sebagai berikut :

Teknik analisis data yang digunakan dalam penelitian ini menggunakan rasio keuangan. Rumus yang digunakan adalah sebagai berikut :

a. Rasio likuiditas

1) Rasio Lancar (current ratio) $=\frac{\text { aktiva lancar }}{\text { hutang lancar }}$

2) Rasio cepat (quick ratio) $=\frac{\text { Aktiva lancar-persediaan }}{\text { hutang lancar }}$

3) Rasio Kas (cash ratio) $=\frac{\text { kas }}{\text { hutang lancar }}$

b. Rasio Solvabilitas
1) $\operatorname{DAR}\left(\right.$ Debt to Assets Ratio) $=\frac{\text { total hutang }}{\text { total aktiva }}$
2) $\operatorname{DER}\left(\right.$ Debt to Equity Ratio) $=\frac{\text { total hutang }}{\text { total modal }}$

c. Rasio Profitabilitas
1) $\operatorname{ROA}($ Return On Asset $)=\frac{\text { Laba Bersih }}{\text { Total aktiva }}$
2) $\operatorname{ROE}\left(\right.$ Return On Equity) = $=\frac{\text { Laba Bersih }}{\text { Modal }}$ 
3) $\mathrm{NPM}$ (Net Profit Margin) $=\frac{\text { Laba bersih }}{\text { Penjualam }}$

\section{HASIL DAN PEMBAHASAN Hasil Penelitian}

Tabel 1 Hasil Perhitungan Rasio Lancar (current ratio) (dalam jutaan rupiah)

\begin{tabular}{|c|c|c|c|c|}
\hline Keterangan & 2015 & 2016 & 2017 & 2018 \\
\hline Aktiva Lancar & 807551112 & 918181510 & 978377431 & 1037077806 \\
\hline Hutang Lancar & 695805147 & 774112760 & 818756339 & 863966681 \\
\hline $\begin{array}{c}\text { Rasio Lancar } \\
(\%)\end{array}$ & 116,05 & 118,61 & 119,49 & 120,03 \\
\hline
\end{tabular}

Pada tahun 2015 dihasilkan rasio sebesar 116.05\% ini menunjukkan bahwa setiap Rp 100,hutang lancer dijamin dengan Rp 116.05 aktiva lancar.

Pada tahun 2016 dihasilkan rasio sebesar 118.61\% ini menunjukkan bahwa setiap Rp 100,hutang lancer dijamin dengan Rp 118.61 aktiva lancar.

Pada tahun 2017 dihasilkan rasio sebesar 119.49\% ini menunjukkan bahwa setiap Rp 100,hutang lancar dijamin dengan Rp 119.49 aktiva lancar.

Pada tahun 2018 dihasilkan rasio sebesar $120.03 \%$ ini menunjukkan bahwa setiap Rp 100,hutang lancar dijamin dengan Rp 120.03 aktiva lancar.

Tabel 2 Hasil Perhitungan Rasio Cepat (quick ratio)

(dalam jutaan rupiah)

\begin{tabular}{|c|c|c|c|c|}
\hline Keterangan & 2015 & 2016 & 2017 & 2018 \\
\hline $\begin{array}{c}\text { Aktiva Lancar } \\
\text { - Persediaan }\end{array}$ & 790385693 & 875591898 & 93205,9754 & 983202477 \\
\hline Hutang Lancar & 695805147 & 774112760 & 818756339 & 863966681 \\
\hline $\begin{array}{c}\text { Rasio Cepat } \\
(\%)\end{array}$ & 113,59 & 113,11 & 113,83 & 113,80 \\
\hline
\end{tabular}

Pada tahun 2015 dihasilkan rasio sebesar 113.59\% ini menunjukkan bahwa setiap Rp 100,- hutang lancar dijamin dengan Rp 113.59 aktiva lancar tanpa persediaan.

Pada tahun 2016 dihasilkan rasio sebesar 113.11\% ini menunjukkan bahwa setiap Rp 100,- hutang lancar dijamin dengan Rp 113.11 aktiva lancer tanpa persediaan.

Pada tahun 2017 dihasilkan rasio sebesar 113.83\% ini menunjukkan bahwa setiap Rp 100,- hutang lancar dijamin dengan Rp 113.83 aktiva lancer tanpa persediaan. 
Pada tahun 2018 dihasilkan rasio sebesar $113.80 \%$ ini menunjukkan bahwa setiap Rp 100,- hutang lancar dijamin dengan Rp 113.80 aktiva lancar tanpa persediaan.

Tabel 3

Hasil Perhitungan Rasio Kas (cash ratio) (dalam jutaan rupiah)

\begin{tabular}{|c|c|c|c|c|}
\hline Keterangan & 2015 & 2016 & 2017 & 2018 \\
\hline Kas & 23118246 & 21223106 & 22005487 & 24443872 \\
\hline Hutang Lancar & 695805147 & 774112760 & 818756339 & 863966681 \\
\hline $\begin{array}{c}\text { Rasio Kas } \\
(\%)\end{array}$ & 3,32 & 2,74 & 2,68 & 2,82 \\
\hline
\end{tabular}

Pada tahun 2015 dihasilkan rasio sebesar 3,32\% ini menunjukkan bahwa setiap Rp 1,- hutang lancar dijamin dengan Rp 3.32 kas untuk memenuhi kewajibannya.

Pada tahun 2016 dihasilkan rasio sebesar 2,74\% ini menunjukkan bahwa setiap Rp 1,- hutang lancer dijamin dengan Rp 2.74 kas untuk memenuhi kewajibannya.

Pada tahun 2017 dihasilkan rasio sebesar 2,68\% ini menunjukkan bahwa setiap Rp 1, hutang lancar dijamin dengan Rp 2.68 kas untuk memenuhi kewajibannya Pada tahun 2018 dihasilkan rasio sebesar 2,82\% ini menunjukkan bahwa setiap Rp 1, hutang lancar dijamin dengan Rp 2.82 kas untuk memenuhi kewajibannya

Tabel 4

Hasil Perhitungan DAR (Debt to Asset Ratio)

(dalam jutaan rupiah)

\begin{tabular}{|c|c|c|c|c|}
\hline Keterangan & 2015 & 2016 & 2017 & 2018 \\
\hline Total Hutang & 695805147 & 774112760 & 818756339 & 863966681 \\
\hline Total Aktiva & 807551112 & 918181510 & 978377431 & 1037077806 \\
\hline Rasio (\%) & 86,16 & 84,30 & 83,68 & 83,30 \\
\hline
\end{tabular}

Pada perhitungan tahun 2015 rasio yang dihasilkan adalah $86,16 \%$ ini menunjukkan bahwa setiap Rp 86.16 hutang dijamin dengan Rp 100,- asset.

Pada perhitungan tahun 2016 rasio yang dihasilkan adalah 84,30\% ini menunjukkan bahwa setiap Rp 84.30 hutang dijamin dengan Rp 100,- asset.

Pada perhitungan tahun 2017 rasio yang dihasilkan adalah 83,68\%, ini menunjukkan bahwa setiap Rp 83.68 hutang dijamin dengan Rp 100,- asset.

Pada perhitungan tahun 2018 rasio yang dihasilkan adalah 83,30\%, ini menunjukkan bahwa setiap Rp 83.30 hutang dijamin dengan Rp 100,- asset.

Tabel 5 Hasil Perhitungan DER (Debt to Equity Ratio)

(dalam jutaan rupiah)

\begin{tabular}{|c|c|c|c|c|}
\hline Keterangan & 2015 & 2016 & 2017 & 2018 \\
\hline Total Hutang & 695805147 & 774112760 & 818756339 & 863966681 \\
\hline Modal & 111745965 & 144068750 & 159621092 & 173111125 \\
\hline Rasio (\%) & 622,67 & 537,32 & 512,94 & 499,08 \\
\hline
\end{tabular}


Pada perhitungan tahun 2015 dihasilkan rasio 622,67\% ini menunjukkan bahwa setiap Rp 622.67 hutang dijamin Rp 100,- modal.

Pada perhitungan tahun 2016 dihasilkan rasio 537,32\% ini menunjukkan bahwa setiap Rp 537.32 hutang dijamin Rp 100,- modal.

Pada perhitungan tahun 2017 dihasilkan rasio 512,94\% ini menunjukkan bahwa setiap Rp 512.94 hutang dijamin Rp 100,- modal.

Pada perhitungan tahun 2018 dihasilkan rasio 499,08\% ini menunjukkan bahwa setiap Rp 499.08 hutang dijamin Rp 100,- modal.

Tabel 6

Hasil Perhitungan ROA

(dalam jutaan rupiah)

\begin{tabular}{|c|c|c|c|c|}
\hline Keterangan & 2015 & 2016 & 2017 & 2018 \\
\hline Laba Bersih & 20104430 & 13071188 & 20010716 & 24078838 \\
\hline Total Aktiva & 807551112 & 918181510 & 978377431 & 1037077806 \\
\hline ROA (\%) & 2,49 & 1,42 & 2,04 & 2,32 \\
\hline
\end{tabular}

Pada tahun 2015 dihasilkan rasio sebesar 2,49\% ini menunjukkan bahwa setiap Rp 1,aktiva menghasilkan Rp 2.49 laba.

Pada tahun 2016 dihasilkan rasio sebesar 1,42\% ini menunjukkan bahwa setiap Rp 1,aktiva menghasilkan Rp 1.42 laba.

Pada tahun 2017 dihasilkan rasio sebesar 2,04\% ini menunjukkan bahwa setiap Rp 1,aktiva menghasilkan Rp 2.04 laba.

Pada tahun 2018 dihasilkan rasio sebesar 2,32\% ini menunjukkan bahwa setiap Rp 1,aktiva menghasilkan Rp 2.32 laba.

Tabel 7

Hasil Perhitungan ROE (Return On Equity)

(dalam jutaan rupiah)

\begin{tabular}{|c|c|c|c|c|}
\hline Keterangan & 2015 & 2016 & 2017 & 2018 \\
\hline Laba Bersih & 20104430 & 13071188 & 20010716 & 24078838 \\
\hline Modal & 111745965 & 144068750 & 159621092 & 173111125 \\
\hline ROE $(\%)$ & 17,99 & 9,07 & 12,53 & 13,90 \\
\hline
\end{tabular}

Pada tahun 2015 dihasilkan rasio sebesar 17,99\% ini menunjukkan bahwa setiap Rp 100,modal menghasilkan Rp 17.99 laba.

Pada tahun 2016 dihasilkan rasio sebesar 9,07\% ini menunjukkan bahwa setiap Rp 100,modal menghasilkan Rp 9.07 laba.

Pada tahun 2017 dihasilkan rasio sebesar 12,53\% ini menunjukkan bahwa setiap Rp 100,modal menghasilkan Rp 12.53 laba.

Pada tahun 2018 dihasilkan rasio sebesar 13,90\% ini menunjukkan bahwa setiap Rp 100,modal menghasilkan Rp 13.90 laba. 
Tabel 8

Hasil Perhitungan NPM

(dalam jutaan rupiah)

\begin{tabular}{|c|c|c|c|c|}
\hline Keterangan & 2015 & 2016 & 2017 & 2018 \\
\hline Laba Bersih & 20104430 & 13071188 & 20010716 & 24078838 \\
\hline Pendapatan & 57891222 & 63142986 & 64736693 & 70882071 \\
\hline NPM (\%) & 34,72 & 20,70 & 30,91 & 33,97 \\
\hline
\end{tabular}

Pada tahun 2015 dihasilkan rasio sebesar 34,72\% ini menunjukkan bahwa setiap Rp 1,- pendapatan menghasilkan Rp 34.72 laba.

Pada tahun 2016 dihasilkan rasio sebesar 20,70\%, ini menunjukkan bahwa setiap Rp 1,pendapatan menghasilkan Rp 20.70 laba.

Pada tahun 2017 dihasilkan rasio sebesar 30,91\% ini menunjukkan bahwa setiap Rp 1,pendapatan menghasilkan Rp 30.91 laba.

Pada tahun 2018 dihasilkan rasio besar 33,97\% ini menunjukkan bahwa setiap Rp 1,- pendapatan menghasilkan Rp 33.97 laba.

\section{KESIMPULAN DAN SARAN}

\section{Kesimpulan}

Terdapat beberapa rasio yang mengalami peningkatan dan penurunan, kinerja keuangan pada Bank Mandiri selama tahun 2015 hingga tahun 2018 dapat dilihat dari rasio sebagai berikut :

a. Likuiditas

Bank Mandiri persero pada kurun waktu 4 tahun 2015-2018 menunjukkan angka rasio yang baik atau liquid. Dilihat dari perhitungan Rasio lancar, Rasio cepat, dan Kas rasio pada kemampuan Bank Mandiri dalam melunasi hutangnya telah dilakukan pengelolaan likuiditas yang baik.

b. Solvabiltias

Bank Mandiri persero pada kurun waktu 4 tahun 2015-2018 menunjukkan angka rasio yang masih baik atau solvable. Hal ini dapat dilihat dari rasio DAR dan DER yang menunjukkan angka rasio yang terus menurun. Dengan ini Bank Mandiri memiliki kemampuan dalam melunasi hutangnya masih dalam keadaan baik, karena sebagian kecil aktiva dan modalnya yang hanya dibiayai menggunakan hutang.

c. Profitabilitas

Bank Mandiri persero pada kurun waktu 4 tahun 2015-2018 menunjukkan angka rasio yang cukup baik walaupun terjadi penurunan angka pada tahun 2016. Turunnnya profitabilitas pada tahun 2016 disebabkan oleh beberapa hal dari pertumbuhan laba bersih yang tidak seimbang dengan pertumbuhan total aktiva, modal dan pendapatan.

\section{Saran}

a. Bank Mandiri harus lebih menjaga dan lebih menekan biaya operasional perusahaan, melakukan review kinerja dan evaluasi dalam menyusun target bisnis dan melakukan langkah-langkah perbaikan dalam rencana strategi dan target bisnis agar tidak terjadi penurunan rasio yang akan merugikan perusahaan.

b. Meningkatkan skill, knowledge, SDM, dan infrastruktur yang diberikan kepada nasabah Bank Mandiri. 
c. Bank Mandiri diharapkan lebih meningkatkan kinerja operasional dan kompetensi seluruh jajaran dalam rangka memberi layanan terbaik kepada seluruh nasabah, mendukung pengembangan potensi perekonomian di seluruh negeri dan meraih pertumbuhan berkualitas berkelanjutan.

\section{DAFTAR PUSTAKA}

Maith,Hendry Andres.2013.Analisis Laporan Keuangan Dalam Mengukur Kinerja Keuangan Pada PT. Hanjaya Mandala Sampoerna Tbk.Manado:Jurnal Ekonomi Manajemen Bisnis dan Akutansi.Vol.1,No.3:619-628.

Manitik,Yunita Irenne.2013. Analisis Perbandingan Kinerja Keuangan Pada PT Xl Axiata Tbk. dan PT Indosat Tbk.Manado:Jurnal Ekonomi Manajemen Bisnis dan Akutansi.Vol.1,No.4:1974-1982

Munawir.2012.Analisa Laporan Keuangan.Yogyakarta:Penerbit Liberty

Ottay,Maikel Ch Dan Stanly W Alexander.2015.Analisis Laporan Keuangan Untuk Menilai Kinerja Keuangan Pada PT. BPR Citra Dumoga Manado.Manado:Jurnal Ekonomi Manajemen Bisnis dan Akutansi.Vol.3,No.1:923-932

Wati,Like Monisa.2012.Pengaruh Praktekgood Corporate Governance terhadap Kinerja Keuangan Perusahaan di Bursa Efek Indonesia.Padang:Jurnal Manajemen. Vol.1,No.1:17. 